\title{
Gastrointestinal adaptation in response to soluble non-available polysaccharides in the rat
}

\author{
BY I. T. JOHNSON AND JENNIFER M. GEE \\ AFRC Food Research Institute Norwich, Colney Lane, Norwich NR4 7UA
}

(Received 11 April 1985 - Accepted 2 January 1986)

\begin{abstract}
1. Rats were fed on a control semi-synthetic diet containing insoluble cellulose (Solkafloc; $100 \mathrm{~g} / \mathrm{kg}$; control group) as the only source of dietary fibre, or on one of two test diets containing the same quantity of either guar gum or carboxymethylcellulose (CMC). Animals in the test groups showed similar growth rates and food intakes, which were significantly lower than those of the control group. The CMC group produced frequent poorly formed faeces throughout the $21 \mathrm{~d}$ feeding period.

2. The small intestines of animals in both test groups were significantly longer than those of the control group at the end of the study. The caeca were also enlarged and heavier, particularly in the CMC-fed group.

3. The rate of production of mucosal cells was increased in the small and large intestines of both test groups. The CMC-fed group exhibited a particularly high rate in the distal ileum, where the rate of cell divisions per crypt was over three times greater than at the same site in the control group. The increased proliferation was associated with a significant lengthening of the crypts and an approximately $25 \%$ increase in the basal width of the villi.

4. Mucosal alkaline phosphatase $(E C$ 3.1.3.1) and lactase $(E C$ 3.2.1.23) levels were lower than those of the control group at proximal and distal sites in the small intestines of both CMC- and guar-gum-fed groups. Altered spatial distributions of maltase $(E C$ 3.2.1.20) and sucrase $(E C$ 3.2.1.48) activities were also observed in these animals.

5. The consumption of at least some gel-forming polysaccharides evidently leads to significant physiological adaptation in the intestinal mucosa of rats, associated with alterations in mucosal cell proliferation. The mechanism underlying this response appears not to be entirely dependent on the physical properties of the chyme.
\end{abstract}

The present broad definition of dietary fibre embraces a variety of materials which differ greatly in their chemical structure and physical properties, but there is, as yet, little theoretical basis on which to predict the physiological effects of particular fibre-rich foods. In previous studies we have investigated the physical behaviour of guar gum and carboxymethylcellulose (CMC) in the small intestine, and described the effects of increased viscosity on the rate of absorption of nutrients (Johnson \& Gee, 1981; Gee et al. 1983). Apart from the immediate effect of guar gum on the viscosity of the chyme, previous studies have also indicated that the prolonged consumption of this material is associated with adaptive changes in the mucosa, including a reduction in the activity of some brush-border enzymes (Johnson et al. 1984). Other workers have reported similar results in rats fed on pectin or galactomannan (Brown et al. 1979; Thomsen \& Tasman-Jones, 1982), but contradictory reports have also recently appeared (Schwartz et al. 1983; Calvert et al. 1985).

The present study is a more detailed investigation of the effects of some soluble, non-available polysaccharides. The two polysaccharides chosen for this investigation form highly-viscous solutions with similar physical properties, although they differ in their chemical structure. Both are widely used for pharmaceutical purposes, and as modifiers of texture by the food industry.

MATERIALS AND METHODS

\section{Animals}

Male Wistar rats (approximately $240 \mathrm{~g}$ ) were obtained from a commercial supplier, allocated randomly to three experimental groups of twelve animals each and housed singly in wire-bottomed cages. Each group received a commercial pellet diet (Labsure CRM; 
Table 1. Composition of the diets $(\mathrm{g} / \mathrm{kg}$ diet $)$

\begin{tabular}{|c|c|c|c|}
\hline $\begin{array}{l}\text { Diet .... } \\
\text { Ingredients }\end{array}$ & Solkafloc (control) & Guar gum & $\begin{array}{l}\text { Carboxymethyl- } \\
\text { cellulose }\end{array}$ \\
\hline Starch* & 260 & 260 & 260 \\
\hline Sucrose & 300 & 300 & 300 \\
\hline Casein $\dagger$ & 200 & 200 & 200 \\
\hline Maize oil & 80 & 80 & 80 \\
\hline Cellulose + & 100 & - & - \\
\hline Guar gums & - & 100 & - \\
\hline Carboxymethylcellulose\| & - & - & 100 \\
\hline Mineral mix & 40 & 40 & 40 \\
\hline Vitamin mix** & 20 & 20 & 20 \\
\hline
\end{tabular}

* 'Snowflake' maize flour; Corn Products Ltd, Manchester.

$\uparrow$ Edible casein; Glaxo Farley foods, Plymouth.

¥ Solkafloc; Johnson Jorgensen, Wettre Ltd., London.

$\S$ Sigma Chemical Co., St Louis, MO, USA.

|| High viscosity Na-carboxymethylcellulose; BDH, Poole, Dorset.

9. Produced the following levels of minerals in the diet ( $/ \mathrm{kg}$ diet): $\mathrm{CaHPO}_{4} 13, \mathrm{CaCO}_{3} 8 \cdot 2, \mathrm{KCl} 7 \cdot 03, \mathrm{Na}_{2} \mathrm{HPO}_{4}$ $7 \cdot 4, \mathrm{MgSO}_{4} \cdot \mathrm{H}_{2} \mathrm{O} 4 \cdot 0, \mathrm{MnSO}_{4} \cdot \mathrm{H}_{2} \mathrm{O} 0 \cdot 18, \mathrm{ZnCO}_{3} 0 \cdot 03, \mathrm{FeSO}_{4} .7 \mathrm{H}_{2} \mathrm{O} 0 \cdot 144, \mathrm{CuSO}_{4} 0.015, \mathrm{KIO}_{3} 0.001$.

** Contained all necessary vitamins at levels equal to, or above, those recommended by the (US) National Research Council (1972) for growth and reproduction.

Christopher Hill Group, Poole, Dorset) for a minimum of $5 \mathrm{~d}$ before receiving an experimental diet ad lib. Body-weights and food intakes were measured daily throughout the study, and food conversion efficiency, defined as body-weight gain $\times 100 /$ food intake, was calculated.

\section{Diets}

The powdered semi-synthetic diets contained equal amounts $(100 \mathrm{~g} / \mathrm{kg})$ of either insoluble cellulose (Solkafloc), CMC, or guar gum. The full compositions are detailed in Table 1.

\section{Mucosal cell proliferation}

The mucosal-cell division-rate was measured by the metaphase arrest technique (Clarke, 1970). Each group of twelve rats received intraperitoneal injections of vincristine sulphate (Sigma, Poole, Dorset) in distilled water $(1 \mathrm{mg} / \mathrm{kg}$ body-weight). The animals were killed successively at 10 -min intervals by stunning and cervical dislocation. The entire small intestine was removed, flushed with saline ( $9 \mathrm{~g}$ sodium chloride $/ 1)$, and extended on the bench with minimal stretching. The length of the intestine was immediately measured, and the first $10 \%$ and the most dista1 $5 \%$ were removed and discarded. Samples (approximately $50 \mathrm{~mm}$ ) were taken from each end and from the middle of the extended intestine, and ligatured to allow precise identification of points corresponding to 10,50 and $95 \%$ of the recorded length. The remaining lengths of small intestine were slit open, laid mucosa uppermost on a glass plate, and scraped with a microscope slide. The mucosal scrapes were then placed in pre-weighed vials, frozen over solid carbon dioxide and stored at $-20^{\circ}$ for subsequent enzyme assay.

The caecum was ligatured immediately adjacent to the ileo-caecal sphincter and caeco-colonic junction, excised, and weighed before and after the removal of the contents by gentle scraping. Samples of tissue (approximately $100 \mathrm{~mm}^{2}$ ) were removed from the proximal caecum, close to the ileo-caecal junction, and from the proximal colon. All tissue samples were fixed and stored in ethanol-acetic acid $(75: 25, \mathrm{v} / \mathrm{v})$ at $3-4^{\circ}$. Subsequent treatment of fixed samples, microdissection and determination of blocked metaphases in 
crypts were carried out as previously described (Johnson et al. 1984). The relation between the increased rates of crypt-cell proliferation seen in both the proximal and distal small intestine of the CMC-fed animals, and some aspects of their mucosal morphology, were investigated in a separate experiment. The dimensions of villi and crypt were estimated as described by Southon et al. (1984).

\section{Analytical methods}

Maltase (EC 3.2.1.20), lactase (EC 3.2.1.23) and sucrase (EC 3.2.1.48). The activities of brush-border disaccharidases in the homogenized mucosal scrapes were assayed by a method based on that of Dahlqvist $(1964,1968)$ and Asp \& Dahlqvist (1972). The diluted homogenates were incubated with the appropriate substrate for $50 \mathrm{~min}$ at $37^{\circ}$ in maleate buffer $(0 \cdot 1 \mathrm{M}, \mathrm{pH} 6 \cdot 0)$. After incubation the samples were further diluted with distilled water, placed in a boiling water-bath for $3 \mathrm{~min}$, cooled and centrifuged $(10000 \mathrm{~g} ; 1 \mathrm{~min})$. The supernatant fractions were assayed directly for glucose by the glucose oxidase $(E C$ 1.1.3.4) method (GOD-Perid; Boehringer, Mannheim, FDR). Blanks were prepared by boiling the homogenate and substrate before incubation.

Alkaline phosphatase (EC 3.1.3.I). Mucosal alkaline phosphatase activity was assayed by a modification of the Sigma method for serum (Sigma Chemical Co., 1980). Diluted homogenate was incubated with substrate in glycine buffer $(0.05 \mathrm{M}, \mathrm{pH} 10.5)$ for 30 min at $37^{\circ}$. The reaction was stopped by the addition of $20 \mathrm{~mm}$-sodium hydroxide, and the absorbance at $400 \mathrm{~nm}$ determined.

Protein. The protein content of the mucosal homogenates was assayed by the method of Lowry et al. (1951). The dry-matter content was determined by oven-drying the homogenates to constant weight at $85^{\circ}$, and correcting for the contribution of saline.

$D N A$. The DNA contents of the mucosal homogenates were measured by the method of Fiszar-Szarfarz et al. (1981), using approximately $0 \cdot 3 \mathrm{~g}$ fresh tissue for each assay.

\section{Statistical methods}

For the comparison of crypt-cell division-rates, the significance of differences between the slopes of lines of best-fit were assessed by means of a $t$ test utilizing pooled sums of squares (Bailey, 1959). The significance of differences between means was assessed using an unpaired $t$ test where comparisons were made between groups, or a paired $t$ test for comparisons within individual animals. In instances where the $F$ test indicated inequality of the sample variances, Satterthwaite's approximation was applied in place of the $t$ test (Conover \& Iman, 1983).

\section{RESULTS}

The diets were readily accepted by the animals, and the three groups each maintained a linear increase in body-weight throughout the 3-week feeding period. The rates of weight gain were, however, significantly slower in the groups given $\mathrm{CMC}$ or guar gum, compared with the Solkafloc-fed control group. The final weights of the CMC- and guar-gum-fed groups were similar, and significantly lower than that of the Solkafloc-fed group. This was associated with both lower food consumption and slightly lower food conversion efficiency (Table 2). The CMC-fed rats produced very wet, poorly-formed faeces throughout the feeding period, although they showed no other signs of ill-health.

\section{Gastrointestinal morphology}

The average lengths of the small intestine from the CMC- and guar-gum-fed groups were similar, and significantly greater than those of the Solkafloc-fed group (Table 3). A striking feature of the CMC-fed animals was the visible enlargement of their caeca in comparison 
Table 2. Food consumption and growth of rats given diets containing cellulose (Solkafloc; $S F)$ carboxymethylcellulose $(C M C)$ or guar gum $(G)$

(Values are means with their standard errors for twelve animals per group)

\begin{tabular}{|c|c|c|c|c|c|c|c|c|c|}
\hline \multirow[t]{2}{*}{ Diet . } & \multicolumn{2}{|c|}{ SF } & \multicolumn{2}{|l|}{ G } & \multicolumn{2}{|c|}{$\mathrm{CMC}$} & \multicolumn{3}{|c|}{$\begin{array}{l}\text { Statistical significance of } \\
\text { differences }\end{array}$} \\
\hline & Mean & $\mathrm{SE}$ & Mean & $\mathrm{SE}$ & Mean & $\mathbf{S E}$ & SF $v \cdot G$ & $\mathrm{SF} v . \mathrm{CMC}$ & $\mathrm{G} v \cdot \mathrm{CMC}$ \\
\hline $\begin{array}{l}\text { Food consumption } \\
\text { (g/animal per } 21 \mathrm{~d})\end{array}$ & 555 & 16 & 429 & 12 & 452 & 10 & $* * *$ & $* * *$ & NS \\
\hline $\begin{array}{l}\text { Body-wt gain } \\
\text { (g/animal per } 21 \mathrm{~d} \text { ) }\end{array}$ & 152 & 8 & 102 & 5 & 106 & 8 & $* * *$ & $* * *$ & NS \\
\hline Final body-wt (g) & 396 & 9 & 346 & 6 & 336 & 8 & $* * *$ & $* * *$ & NS \\
\hline $\begin{array}{l}\text { Food conversion } \\
\text { efficiency } \dagger\end{array}$ & $27 \cdot 3$ & 0.8 & $23 \cdot 9$ & 0.8 & $23 \cdot 4$ & 1.5 & $* *$ & $*$ & NS \\
\hline
\end{tabular}

NS, not significant.

$* P<0.05, * * P<0.01, * * * P<0.001$.

$\uparrow$ Body-wt gain $\times 100 /$ food intake.

Table 3. Small intestinal length, caecal weight and weight of caecal contents in rats given diets containing cellulose (Solkafloc; $S F$ ), carboxymethylcellulose $(C M C)$ or guar gum $(G)$

(Values are means with their standard errors for twelve animals per group)

\begin{tabular}{|c|c|c|c|c|c|c|c|c|c|}
\hline \multirow[t]{2}{*}{ Diet... } & \multicolumn{2}{|l|}{ SF } & \multicolumn{2}{|l|}{ G } & \multicolumn{2}{|c|}{ CMC } & \multicolumn{3}{|c|}{$\begin{array}{c}\text { Statistical significance of } \\
\text { differences }\end{array}$} \\
\hline & Mean & SE & Mean & SE & Mean & SE & SF $v \cdot G$ & $\mathrm{SF} v . \mathrm{CMC}$ & $\mathrm{G} v . \mathrm{CMC}$ \\
\hline $\begin{array}{l}\text { Length of small } \\
\text { intestine }(\mathrm{mm})\end{array}$ & 1130 & 20 & 1330 & 20 & 1350 & 20 & $* * *$ & $* * *$ & NS \\
\hline $\begin{array}{l}\text { Wt of caecum } \\
\text { (g wet wt) }\end{array}$ & 0.65 & 0.02 & 1.85 & 0.05 & $2 \cdot 45$ & 0.11 & $* * *$ & $* * *$ & $* * *$ \\
\hline $\begin{array}{l}\text { Wt of caccal contents } \\
\text { (g wet wt) }\end{array}$ & 2.01 & $0 \cdot 13$ & $4 \cdot 26$ & 0.27 & $11 \cdot 06$ & 0.73 & $* * *$ & $* * *$ & $* * *$ \\
\hline $\begin{array}{l}\text { Wt of caecal contents } \\
\text { (g dry wt) }\end{array}$ & 0.64 & 0.02 & 0.74 & 0.05 & $1 \cdot 85$ & 0.13 & NS & $* * *$ & $* * *$ \\
\hline $\begin{array}{l}\text { Dry matter content } \\
\text { of caecal contents } \\
(\mathrm{g} / \mathrm{kg})\end{array}$ & 315 & 7 & 175 & 10 & 167 & 2 & $* * *$ & $* * *$ & NS \\
\hline
\end{tabular}

NS, not significant.
$* * * P<0 \cdot 001$

with those of the other two groups. The relative weights of the caecal tissue, together with those of the contents, are given in Table 3. The CMC- and guar-gum-fed groups possessed enlarged caeca, containing more material than those of the animals fed on Solkafloc. The water content of caecal material recovered from the guar-gum- and CMC-fed rats was also significantly higher than that from the Solkafloc-fed group.

\section{Mucosal cell proliferation}

Significantly higher rates of crypt-cell division were observed in the CMC-and guar-gum-fed groups compared with the Solkafloc-fed control group, at all three positions in the small 


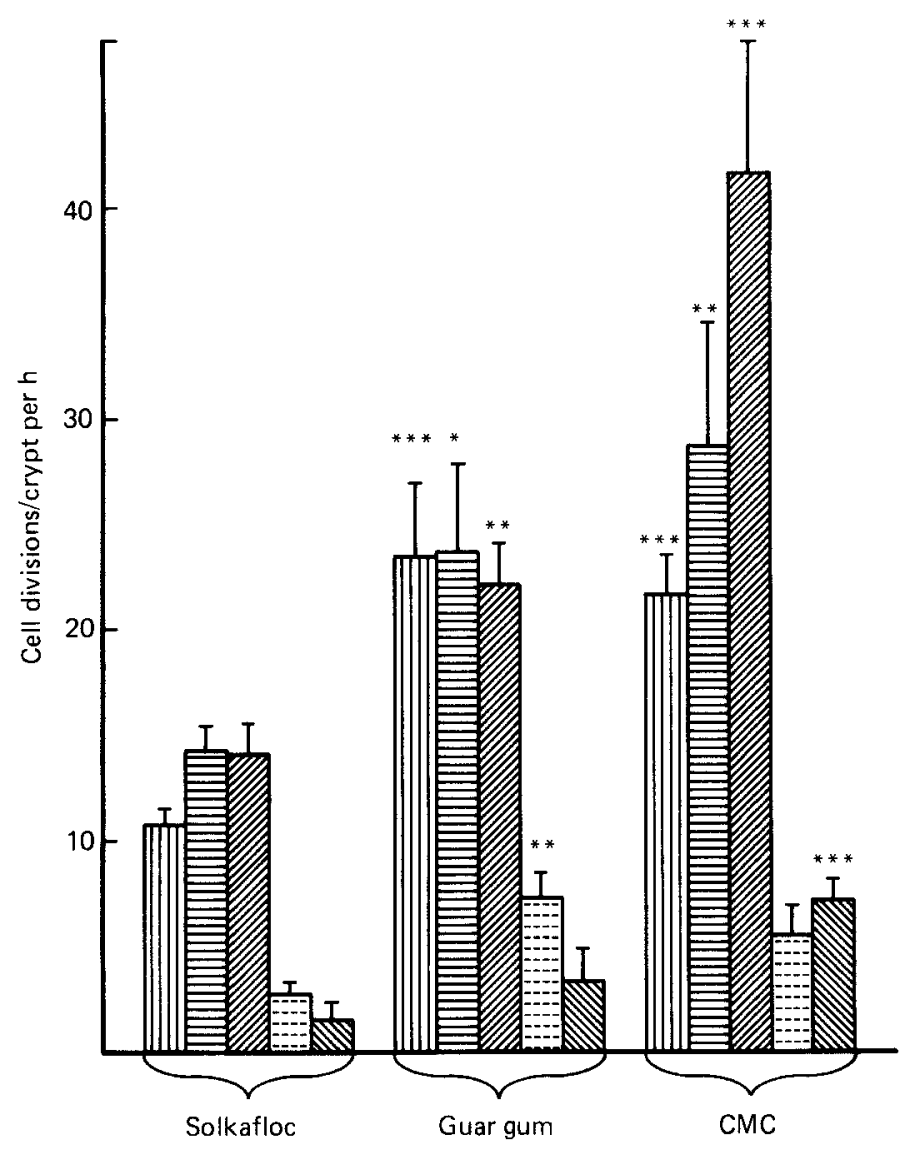

Fig. 1. Rates of mucosal cell proliferation at positions 10\% (四), 50\% (园) and $95 \%$ (国) of the total small-intestinal length from the pyloric sphincter, and at sites in the proximal caecum (国) and colon (Mean rates of cell divisions/crypt per h differed significantly from equivalent values in the control (Solkafloc) group: * $P<0.05,{ }^{* *} P<0.01,{ }^{* * *} P<0.001$. The rate of proliferation at the distal ileum $(95 \%)$ of the carboxymethylcellulose (CMC)-fed rats differed significantly from the rate at the proximal jejunum $(10 \%)$ within the same group $(P<0.01)$, and from the rate at the distal ileum of the guar-gum-fed group $(P<0.005)$. Values are means with their standard errors represented by vertical bars.

intestine. There was also evidence of higher division rates in the large intestines of these animals, but the statistical significance of the observations was lower.

An important feature of these results is that the adaptive response of the small intestine to the two soluble polysaccharides was different. Whereas in both the Solkafloc- and guar-gum-fed animals the crypt-cell division-rate was approximately the same at each of the three sites in the small intestine, in the CMC-fed group the rate became progressively higher toward the ileo-caecal junction (Fig. 1).

In both the CMC-fed and the Solkafloc-fed animals, the villi were significantly smaller in the distal ileum than in the jejunum $(P<0 \cdot 001)$. The increased rate of cell division was not associated with significant differences in the height of villi between the groups but the basal width of the villi was significantly greater in the CMC-fed animals (Table 4). The average length of the crypts in the CMC-fed group was greater than that of the Solkafloc-fed group at both sites (Table 4 ), and the ileal crypts were significantly longer than those of the proximal jejunum $(P<0.001)$. 
Table 4. Cell division rates and dimensions of villi and crypts in proximal jejunum and distal ileum of rats given diets containing cellulose (Solkafloc; SF) or carboxymethylcellulose (CMC)

(Values are means with their standard errors for ten animals per group)

\begin{tabular}{|c|c|c|c|c|c|}
\hline \multirow[t]{2}{*}{ Diet... } & \multicolumn{2}{|c|}{ SF } & \multicolumn{2}{|c|}{$\mathrm{CMC}$} & \multirow{2}{*}{$\begin{array}{c}\begin{array}{c}\text { Statistical } \\
\text { significance } \\
\text { of differences }\end{array} \\
\text { SF v. CMC }\end{array}$} \\
\hline & Mean & $\mathrm{SE}$ & Mean & $\mathrm{SE}$ & \\
\hline \multicolumn{6}{|l|}{ Proximal jejunum } \\
\hline Cell division rate (divisions/crypt per h) & $11 \cdot 7$ & $1 \cdot 3$ & $19 \cdot 8$ & 1.6 & $* *$ \\
\hline Villous height $(\mu \mathrm{m})$ & 624 & 19 & 631 & 21 & NS \\
\hline Villous width $(\mu \mathrm{m})$ & 601 & 36 & 709 & 25 & $\bullet$ \\
\hline Crypt length $(\mu \mathrm{m})$ & 136 & 5 & 210 & 5 & $* * *$ \\
\hline \multicolumn{6}{|l|}{ Distal ileum } \\
\hline Cell division rate (divisions/crypt per h) & $11 \cdot 4$ & $1 \cdot 5$ & $35 \cdot 5$ & 3.9 & $* * *$ \\
\hline Villous height $(\mu \mathrm{m})$ & 313 & 14 & 299 & 10 & NS \\
\hline Villous width $(\mu \mathrm{m})$ & 367 & 20 & 456 & 13 & $* *$ \\
\hline Crypt length $(\mu \mathrm{m})$ & 151 & 4 & 279 & 8 & $* * *$ \\
\hline
\end{tabular}

NS, not significant.

${ }^{*} P<0.05,{ }^{* *} P<0.01,{ }^{* * *} P<0.001$.

Table 5. Mucosal enzyme activities and protein and DNA contents in rats given diets containing cellulose (Solkafloc; $S F$ ), carboxymethylcellulose $(C M C)$ or guar gum $(G)$

(Values are means with their standard errors for twelve animals per group)

\begin{tabular}{|c|c|c|c|c|c|c|c|c|c|}
\hline \multirow[t]{2}{*}{ Diet... } & \multicolumn{2}{|c|}{$\mathrm{SF}$} & \multicolumn{2}{|c|}{ G } & \multicolumn{2}{|c|}{$\mathrm{CMC}$} & \multicolumn{3}{|c|}{$\begin{array}{c}\text { Statistical significance of } \\
\text { differences }\end{array}$} \\
\hline & Mean & $\mathrm{SE}$ & Mean & SEM & Mean & $\mathrm{SE}$ & $\mathrm{SF} v \cdot \mathrm{G}$ & SF v. CMC & G v. CMC \\
\hline \multicolumn{10}{|l|}{ Jejunum } \\
\hline \multicolumn{10}{|l|}{$\begin{array}{l}\text { Enzyme activity } \\
\text { (units/mg DNA): }\end{array}$} \\
\hline Sucrase $(E C 3.2 .1 .48)$ & 1.5 & 0.09 & $1 \cdot 5$ & $0 \cdot 20$ & $1 \cdot 4$ & 0.21 & NS & NS & NS \\
\hline Maltase $(E C 3.2 .1 .20)$ & $18 \cdot 4$ & 2.94 & $11 \cdot 5$ & 1.43 & $17 \cdot 7$ & $3 \cdot 10$ & $*$ & NS & NS \\
\hline Lactase $(E C 3.2 .1 .23)$ & $0 \cdot 30$ & 0.02 & 0.15 & 0.02 & 0.12 & 0.02 & $* * *$ & $* * *$ & NS \\
\hline $\begin{array}{l}\text { Alkaline phosphatase } \\
(E C 3.1 .3 .1)\end{array}$ & 7.9 & 0.65 & $3 \cdot 5$ & 0.28 & $3 \cdot 2$ & 0.59 & $* * *$ & $* * *$ & NS \\
\hline $\begin{array}{r}\text { Mucosal DNÁ } \\
\text { (mg/g dry wt) }\end{array}$ & 14.9 & 0.78 & $15 \cdot 1$ & 0.92 & $15 \cdot 1$ & 1.42 & NS & NS & NS \\
\hline $\begin{array}{l}\text { Mucosal protein } \\
\text { (mg/g dry wt) }\end{array}$ & 387 & $9 \cdot 1$ & 388 & $8 \cdot 2$ & 352 & $12 \cdot 8$ & $* * *$ & * & NS \\
\hline \multicolumn{10}{|l|}{ Ileum } \\
\hline \multicolumn{10}{|l|}{$\begin{array}{l}\text { Enzyme activity } \\
\text { (units/mg DNA): }\end{array}$} \\
\hline Sucrase & 1.7 & $0 \cdot 12$ & $3 \cdot 1$ & 0.33 & 1.8 & 0.11 & $* * *$ & NS & $* * *$ \\
\hline Maltase & $17 \cdot 1$ & 1.76 & $17 \cdot 1$ & 1.66 & $9 \cdot 2$ & 0.74 & NS & $* * *$ & $* * *$ \\
\hline Lactase & 0.27 & 0.04 & $0 \cdot 13$ & 0.02 & 0.03 & 0.01 & $* *$ & $* * *$ & **** \\
\hline Alkaline phosphatase & 3.6 & $0 \cdot 39$ & $2 \cdot 3$ & 0.15 & $2 \cdot 0$ & $0 \cdot 18$ & $* * *$ & *** & NS \\
\hline $\begin{array}{c}\text { Mucosal DNÁ } \\
\text { (mg/g dry wt) }\end{array}$ & $10 \cdot 3$ & $0 \cdot 78$ & $9 \cdot 8$ & 0.89 & $9 \cdot 2$ & 0.46 & NS & NS & NS \\
\hline $\begin{array}{l}\text { Mucosal protein } \\
\text { (mg/g dry wt) }\end{array}$ & 267 & $6 \cdot 5$ & 216 & $13 \cdot 0$ & 241 & $11 \cdot 5$ & $* * *$ & NS & NS \\
\hline
\end{tabular}

NS, not significant.

* $P<0.05,{ }^{* *} P<0.01,{ }^{* * *} P<0.001$. 


\section{Mucosal enzyme activities}

The activities of brush-border disaccharidases and of alkaline phosphatase in proximal and distal small intestine from the three dietary groups are given in Table 5. The values are expressed in terms of DNA to provide an indication of average cellular levels of these enzymes in the mucosa. Average DNA and protein contents of the mucosa are also provided. The alkaline phosphatase activity of mucosa from both proximal and distal intestine was significantly lower in both the CMC- and guar-gum-fed groups compared with the Solkafloc-fed group. Of the dissacharidases, lactase activity also was lower at both sites, in both test groups, and was particularly low in the distal intestine of the CMC-fed group. The changes in maltase activity were slightly more complicated. There was a reduction in maltase activity in the proximal intestine of the guar-gum-fed group, compared with that of the Solkafloc-fed group, but not in the distal segment, whereas in the CMC-fed animals the reverse was true. Sucrase activity in the jejunum appeared not to be significantly affected by the non-absorbable polysaccharide content of the diet, but the activity was significantly increased in the ileum of the guar-gum-fed group.

\section{DISCUSSION}

It is now widely accepted that fibre has an important role in human nutrition, and that a general increase in its consumption by Western populations is desirable. However, in view of the variety of materials included under the present definition of dietary fibre, many questions remain as to the most beneficial sources and the optimal daily intake. To resolve these problems, a better understanding of the physiological changes brought about in the mammalian gut by particular components of dietary fibre is needed. The present study demonstrates that the small intestine and caecum of rats fed on soluble, gel-forming gums (CMC and guar gum) show significant adaptive differences when compared with those of animals fed on similar quantities of insoluble cellulose. Furthermore, even hydrocolloid gums having similar physical properties can provoke distinctly different effects.

The most important morphological changes seen in the present study occurred in the large intestine, where the wet weight of the caecal tissue increased nearly threefold in the guar-gum-fed group, and nearly fourfold in the CMC-fed group, compared with controls. The enlargement of the rat caecum in response to the consumption of non-digestible polysaccharides has been frequently reported but remains poorly understood. Recently, Jacobs \& Lupton (1984) described changes in caecal growth and mucosal cytokinetics in rats fed on various components of dietary fibre, and concluded that readily fermentable polysaccharides give rise to greater caecal enlargement than poorly degraded materials. This suggests that the fermentation products of non-digestible carbohydrates may be the trophic factor, a possibility which is supported by the fact that wholly non-fermentable bulking agents do not seem to stimulate mucosal growth (Dowling et al. 1967; Goodlad \& Wright, 1983), and by the recent observations of Sakata \& Engelhardt (1983), showing that infused short-chain fatty acids stimulate epithelial cell proliferation in the large intestine of the rat.

Other mechanisms have been proposed to explain diet-induced caecal enlargement, including increased osmolarity of the caecal contents (Leegwater et al. 1974), and retention of water by hydrocolloids in the caecal lumen (Konishi et al. 1984). In the present study, the water content of the intracaecal material of both test groups was increased, to a similar extent, in comparison with the controls. However, the CMC-fed rats had a significantly larger mass of intracaecal material than both the other groups, and also had persistent diarrhoea.

In contrast to the caecum, the changes in small intestinal morphology seen in the test 
groups were relatively slight. Although the substantially-increased rates of mitosis were associated with a consistent enlargement of the crypts, the only significant alteration in villous dimensions was a broadening of the basal width, amounting to about $24 \%$ of the control value, in the distal ileum of the CMC-fed rats. The control rats had similar rates of crypt-cell mitosis at the proximal, mid- and distal intestinal positions; this is consistent with the results of previous studies using conventionally fed rats (Clarke, 1970). The consumption of guar gum led to a uniform increase in mitosis at each site, but in the CMC-fed group the rate was progressively higher in the more distal positions. Since guar gum and CMC have similar properties in aqueous solution, this unusual pattern suggests that the stimulus to crypt-cell division is some factor other than the greater viscosity of the chyme. A possible connection with bacterial fermentation is suggested by the recent work of Sakata \& Yajima (1984), showing that short-chain fatty acids infused into the large bowel also stimulate cell division in the small intestine.

Although the consumption of the hydrocolloid gums was associated with only minor alterations in mucosal morphology in the small intestine, important changes in the activities of some brush-border enzymes were observed. As we (Johnson et al. 1984) and others (Calvert et al. 1985) have pointed out, there is considerable disagreement in recent literature as to the effects of various components of dietary fibre on mucosal enzyme activity. Several workers have reported decreased disaccharidase activity in rats fed on pectin- or galactomannan-supplemented diets (Brown et al. 1979; Thomsen \& Tasman-Jones, 1982), whilst others report unchanged or slightly elevated levels (Schwartz et al. 1983; Calvert et al. 1985). The present results are consistent with our previous work, to the extent that both the test groups had reduced lactase and alkaline phosphatase activities in the proximal and distal intestinal segments, whilst sucrase activity in the proximal segment was unaffected by $\mathrm{CMC}$ and guar gum. However, a more complex pattern now emerges in relation to maltase and sucrase activity in the distal segments. Maltase was reduced only in the proximal segments of the guar-gum-fed group, and only in the distal segment of the CMC-fed group, whilst a significant increase in sucrase activity occurred in the distal segment of the guar-gum-fed animals.

These changes, and the various discrepancies which exist in the current literature, pose a complex problem which probably reflects the fact that the expression of enzyme activities in the small-intestinal brush-border is subject to several regulatory pressures. A reduction in average cell lifespan, brought about by increased production of new cells in the crypts, will shorten the time available for the development of enzyme activity. The quantitative significance of this will vary for different enzymes, depending on the relative rates at which their activities are expressed during the maturation of the absorptive cells. This probably explains the reductions in alkaline phosphatase and lactase activities seen in both intestinal segments of the guar-gum-fed animals. Superimposed on this, however, is the regulation of brush-border disaccharidases by lumen carbohydrate, which is known to take place both in rats (Yamada et al. 1983; Goda et al. 1983) and in man (Rosenweig, 1975). The presence of a viscous gel will delay absorption of carbohydrate and hence increase the concentration of substrate to which the mucosal cells are exposed at more distal sites (Blackburn \& Johnson, 1981). Induction of disaccharidases in the lower part of the intestine may thus have tended to counteract the effect of a reduced cell-lifespan in the guar-gum-fed group.

If the subtle changes in gastrointestinal physiology observed in the present study also occur in man, there may be important practical consequences. The use of glucosidase inhibitors such as acarbose, to reduce the rate of disaccharidase hydrolysis, and hence delay carbohydrate absorption in metabolic diseases, is now being actively pursued (Puls et al. 1982). If a significant reduction or change in the distribution of endogenous enzyme activity could be achieved in man by the consumption of particular soluble polysaccharide 
supplements, this might provide a useful alternative to the use of drugs. On the other hand, a reduction in lactase activity induced by polysaccharide supplements would be undesirable for persons at risk of developing lactose intolerance.

The putative beneficial effects of fibre in the human large bowel are generally thought to result from increased faecal bulk and the consequent reductions in intraluminal pressure and transit time (Burkitt et al. 1974). The possibility of adaptive trophic changes in the bowel has received less attention, but the effects on large intestinal growth and mucosal proliferation seen here in rats seem likely to be of relevance to the development of diverticulae. Furthermore, Jacobs (1983) has recently shown that the induction of colonic carcinogenesis in the rat is enhanced by increased mucosal proliferation brought about by wheat bran. Further studies of the relation between the chemical structure of particular components of dietary fibre and the physiological responses which they evoke in the human large bowel would therefore seem warranted.

The authors are grateful to Mr M. D. Rhodes and Miss J. Brown for technical assistance, and to Mrs J. Cooke and Mr P. Muddel for care of the experimental animals.

\section{REFERENCES}

Asp, N. G. \& Dahlquist, A. (1972). Analytical Biochemistry 47, 527-538.

Bailey, N. T. J. (1959). Statistical Methods in Biology, p. 99. London: English Universities Press.

Blackburn, N. A. \& Johnson, I. T. (1981). British Journal of Nutrition 46, 239-246.

Brown, R. C., Kelleher, J. \& Losowsky, M. S. (1979). British Journal of Nutrition 42, 357-365.

Burkitt, D. P., Walker, A. R. P. \& Painter, N. S. (1974). Journal of the American Medical Association 229, 1068-1074.

Calvert, R., Schneeman, B. O., Satchithanandam, S., Cassidy, M. M. \& Vahouny, G. V. (1985). American Journal of Clinical Nutrition 41, 1249-1256.

Clarke, R. M. (1970). Journal of Anatomy 107, 519-529.

Conover, W. J. \& Iman, R. L. (1983). Introduction to Modern Business Statistics, p. 291. New York: John Wiley.

Dahlqvist, A. (1964). Analytical Biochemistry 7, 18-25.

Dahlquist, A. (1968). Analytical Biochemistry 22, 99-107.

Dowling, R. H., Riecken, E. O., Laws, J. W. \& Booth, C. C. (1967). Clinical Science 32, 1-9.

Fiszar-Szarfarz, B., Szarfarz, D. \& Guevara de Murillo, A. (1981). Analytical Biochemistry 110, 165-170.

Gee, J. M., Blackburn, N. A. \& Johnson, I. T. (1983). British Journal of Nutrition 50, 215-224.

Goda, T., Yamada, K., Bustamante, S. \& Koldovsky, O. (1983). American Journal of Physiology 245, G418-G423.

Goodlad, R. A. \& Wright, N. A. (1983). British Journal of Nutrition 50, 91-98.

Jacobs, L. R. (1983). Cancer Research 43, 4057-4061.

Jacobs, L. R. \& Lupton, J. R. (1984). American Journal of Physiology 246, G378-G385.

Johnson, I. T. \& Gee, J. M. (1981). Gut 22, 398-403.

Johnson, I. T., Gee, J. M. \& Mahoney, R. R. (1984). British Journal of Nutrition 52, 477-487.

Konishi, F., Shidoji, Y., Oku, T. \& Hosuya, N. (1984). Japanese Journal of Experimental Medicine 54, $139-142$.

Leegwater, D. C., de Groot, A. P. \& Kalmthout-Kuyper, M. van (1974). Food \& Cosmetics Toxicology 12, 687-697.

Lowry, O. H., Roseborough, N. J., Farr, A. L. \& Randall, R. J. (1951). Journal of Biological Chemistry 193, $265-275$.

National Research Council (1972). Nutrient Requirements of Laboratory Animals, p. 64, 2nd ed. Washington DC: National Academy of Sciences.

Puls, W, Keup, U., Krause, H. P., Thomas, G. \& Hoffmeister, F. (1982). Proceedings--First International Symposium on Acarbose Effects on Carbohydrate \& Fat Metabolism, pp. 16-27 [W. Creutzfeldt, editor]. Amsterdam: Excerpta Medica.

Rosenweig, N. S. (1975). American Journal of Clinical Nutrition 28, 648-655.

Sakata, T. \& Engelhardt, W. von (1983). Comparative Biochemistry \& Physiology 74A, 459-462.

Sakata, T. \& Yajima, T. (1984). Quarterly Journal of Experimental Physiology 69, 639-648.

Schwartz, S. E., Starr, C., Backman, S. \& Holtzapple, P. G. (1983). Journal of Lipid Research 24, 746-752.

Sigma Chemical Co. (1980). Sigma Technical Bulletin no. 104. St Louis, Missouri: Sigma Chemical Co.

Southon, S., Gee, J. M. \& Johnson, I. T. (1984). British Journal of Nutrition 52, 371-380.

Thomsen, L. L. \& Tasman-Jones, C. (1982). Digestion 23, 253-258.

Yamada, K., Goda, T., Bustamante, S. \& Koldovsky, O. (1983). American Journal of Physiology 244, G449-G455. 